\title{
Sandy desertification: Borne on the wind
}

\author{
WANG XunMing \\ Key Laboratory of Desert and Desertification, Cold and Arid Regions Environmental and Engineering Research Institute, Chinese Academy of \\ Sciences, Lanzhou 730000, China
}

Received November 20, 2012; accepted January 31, 2013; published online March 26, 2013

\begin{abstract}
Sandy desertification is both an inherently interesting bioscience and geoscience topic and an important topic from the perspectives of the ecological environment and food security. It has therefore increasingly attracted the attention of the public, in addition to researchers, government officials, and international organizations. This paper reviews the development of knowledge on sandy desertification, research progress in understanding the physical and biological processes involved in sandy desertification, and the significance of wind activity in determining the increases and decreases in sandy desertification. Based on this review of current research on the mechanisms and processes of sandy desertification, combining geological and biological sciences appears likely to improve our understanding of this complex system, thereby providing a more holistic understanding of sandy desertification at a range of temporal and spatial scales.
\end{abstract}

aeolian desertification, sandy desertification, wind activity, dune activity, physical processes, biological processes

Citation: Wang X M. Sandy desertification: Borne on the wind. Chin Sci Bull, 2013, 58: 2395-2403, doi: 10.1007/s11434-013-5771-9

The severe drought events in western Africa during the 1960 s and 1970s caused equally severe land degradation and food shortages [1], creating a global awareness of the desertification problem and attracting the attention of scholars, governments, and international organizations. The importance of this problem for the global ecological environment and for human life led to a flurry of research, accompanied by much debate over the concepts, connotations, and causes of desertification [2-5]. However, in areas that have become research hotspots, the debate has often focused on defending certain views or safeguarding certain interests [6-10].

The concepts of desertification and sandy desertification were proposed as early as the 1900s [11], but at that time, no major distinctions were made among the different connotations of these terms [12]. For instance, before 1977, desertification was usually defined using terms such as desert advance, desert creep, and desert expansion [13,14], or grassland degradation caused by wind erosion and land productivity degradation caused by drought [15]. However,

email: xunming@1zb.ac.cn the 1977 Nairobi meeting of the United Nations Conference on Desertification (UNCD) defined desertification as: “... the diminution or destruction of the biological potential of the land, (which) can lead ultimately to desert-like conditions" [16]. Based on these connotations, the United Nations Environment Programme (UNEP) stated in 1992 that desertification should be defined as "land degradation in arid, semi-arid and dry sub-humid areas resulting from various factors including climatic variations and human activities" $[17,18]$, and compiled the World Atlas of Desertification $[19,20]$; most of this document was adopted as the United Nations Convention to Combat Desertification in Those Countries Experiencing Serious Drought and/or Desertification, Particularly in Africa.

As the concept of desertification evolved, scholars gradually realized that sandy desertification was only one of several kinds of desertification, and to distinguish it from other forms of desertification, sandy desertification was usually defined as "aeolian desertification" [21]. However, as was the case for the definition of desertification, the definition of sandy desertification has also evolved through several stages. For instance, in the early 1980s, Zhu et al. 
[22] proposed that sandy desertification resulted from a combination of human activities and changing natural conditions during human history that have led to the development of desert-like conditions in non-desert regions. He subsequently revised the definition to include the destruction of an ecological balance as a result of excessive human activities under conditions characterized by high wind activity in regions with sandy surface sediments, accompanied by signs of strengthening wind activity simultaneous with the appearance of land degradation [23]. In addition, Yang et al. [24] defined sandy desertification as a series of climate and geomorphological processes that occur in areas with sandy surface sediments in arid, semiarid, and sometimes semihumid areas over a range of time scales, with wind and other factors acting as the major dynamic factors. Dong et al. [25] proposed that wind activity was the major cause of desertification during the environmental change processes that are occurring in non-desert regions.

$\mathrm{Wu}[26,27]$ insisted that the exact definition of sandy desertification required accounting for processes that destroy the ecological balance in arid, semiarid, and semihumid areas and that result from a combination of human activities and changes in various natural factors, with increased wind activity as the major cause; these changes lead to the development of desert-like landscapes in non-desert regions or the expansion of existing deserts. Later, he expanded his definition to include the concept that sandy desertification also represented the formation and expansion of deserts, and noted that the desertification that has occurred within human history represents only the most recent episodes of desertification, which has occurred previously on a geological time scale [28]. Wu's last definition seems to most clearly describe the essential points and key connotations of sandy desertification. Most of the abovementioned definitions agreed that wind activity was the most distinctive cause of sandy desertification. The main landscape changes that occur during desertification include dune reactivation, coarsening of the surface sediments, desertification of grassland, and other related processes [29]. Therefore, from the perspective of the key erosive force, sandy desertification can be defined as aeolian desertification or winderosion desertification [30].

\section{Relationships between wind activity and sandy desertification}

At global and regional scales, wind plays an important role in geomorphological processes and environmental change. However, even after the debate over terminology described in the previous section, there were still no distinct descriptions of the relationship between wind activity and sandy desertification. In arid, semiarid, and some semihumid areas, the erosion, transportation, and deposition of surface sediments by the wind are the key aeolian processes [31-33].
Therefore, from the perspective of geomorphology, sandy desertification is a land degradation process in which wind activity is the key dynamic factor, and sandy desertification is a predominantly aeolian process. The wind activity creates both erosion landforms such as deflation basins and valleys, erosion remnants, and pans, and deposition landforms such as the many different dune morphologies.

As aeolian geomorphology forms and evolves, sandy desertification and its reversal may both occur. On the one hand, wind-eroded fine particles with abundant nutrients bound to their surface have potentially large impacts on plant growth: where they are removed by the wind, growth suffers, but where they are deposited, growth may improve [34]. On the other hand, in areas with high sediment availability such as sandy lands and the margins of deserts with mobile dunes, there are complex associations between vegetation activity and aeolian processes. For instance, during periods with low wind activity, fine particles may accumulate around plants, and the nutrients bound to the surface of these particles can accelerate plant growth, potentially stabilizing mobile sands and reversing desertification [35-45]. Conversely, during periods with high wind activity, these fine particles may be eroded and transported away from the plants, leading to coarsening of the surface soil, and if plant growth and survival decrease sufficiently, anchored and semi-anchored dunes may evolve into semi-mobile and mobile dunes, causing an increase in sandy desertification [46-48]. As a result of these contrasting processes, sandy lands and the margins of mobile deserts reveal a strong and fundamental association between sandy desertification and wind activity: during periods with high wind activity, sandy desertification increases, and during periods of low wind activity, it decreases [49-52]. In addition to sandy lands and the margins of deserts with mobile dunes, steppes and reclaimed grasslands are also at risk of sandy desertification. However, due to limitations on sediment availability in these regions, there are few large-scale examples of aeolian geomorphology, and distinct geomorphological signals of sandy desertification are absent. For these regions, however, there is also a close relationship between sandy desertification and wind activity: high wind activity erodes more of the soil's fine particles and removes the associated nutrients from the surface sediments, impoverishing and coarsening the soil. This can adversely affect vegetation, leading to sandy desertification.

Recent studies from around the world, including an extensive survey of the literature by the United States Department of Agriculture (Figure 1), have revealed that areas with high wind erosion risks in arid, semiarid, and some semihumid regions are usually also areas at high risk of desertification. These regions include parts of western Africa and Australia. Northern Africa, the Mongolian Plateau, and parts of arid and semiarid central Asia lack a detailed classification of the wind erosion risk or vulnerability to desertification due to their extremely arid climate or a lack 

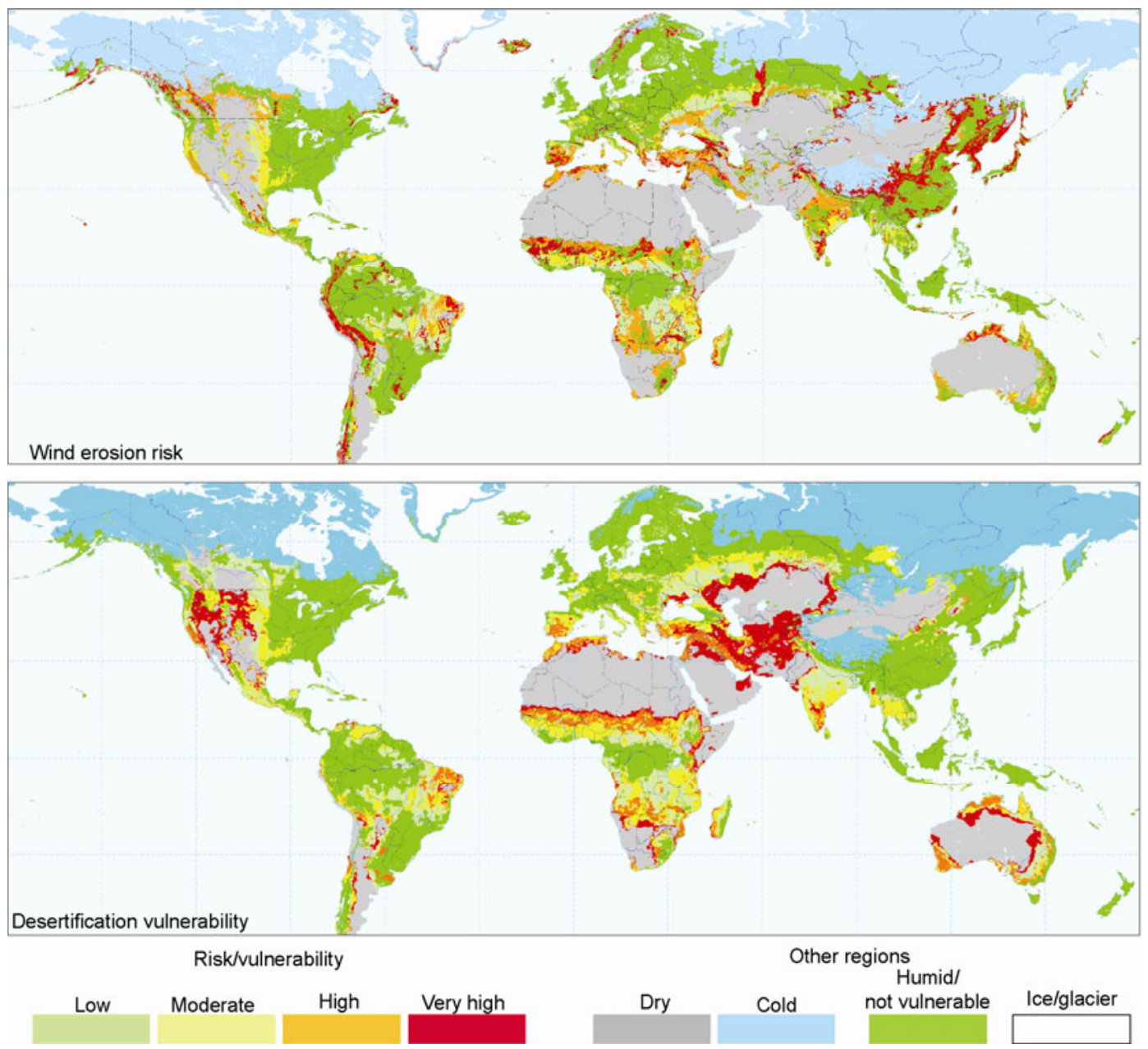

Figure 1 Global wind erosion risk and the corresponding desertification vulnerability. Data source: United States Department of Agriculture, http://soils. usda.gov/use/worldsoils/mapindex/dsrtrisk.html.

of data. However, aeolian geomorphologies have developed extensively in these areas, and based on what we do know of these areas, it seems likely that wind activity and desertification occurrence are closely related.

For arid, semiarid, and some semihumid regions of China, the United States Department of Agriculture did not provide sufficient details about the spatial variation in desertification vulnerability and wind erosion risks. However, recent Chinese research has also shown that regions with high wind activity are also highly vulnerable to desertification $[29,53]$. Since 1940, the temporal trends in wind activity have been highly consistent with the trends in sandy desertification [54,55] (Figure 2). For instance, strengthening of wind activity in northern China starting in the 1950s was associated with a period of increasing sandy desertification; in particular, from the 1970s to the 1980s, the highest wind activity during this period was observed, accompanied by low spring precipitation, leading to the greatest increase in sandy desertification during this period [56]. In contrast, as wind activity decreased during the 1980s and the 1990s, sandy desertification decreased [55-57]. Ecological re- search has shown that sandy desertification is also caused by variations in the vegetation cover and in biomass [58]; nonetheless, despite the influence of biological processes on sandy desertification, physical processes such as wind activity seem to have played the most important role in sandy desertification, as the rest of this paper will demonstrate.

\section{Advances in current research on sandy desertification}

Based on the current definition, sandy desertification mainly occurs at the margins of deserts with mobile dunes, and in sandy lands, steppes, and reclaimed grasslands that once had relatively high vegetation productivity. Changes in precipitation or groundwater levels, combined with high sediment availability and wind activity, lead to the development of different dune morphologies, although the development process is affected by the vegetation cover and biomass [59-61]. When dunes appear in dune fields, the areas are typically defined as sandy land, and depending on the 


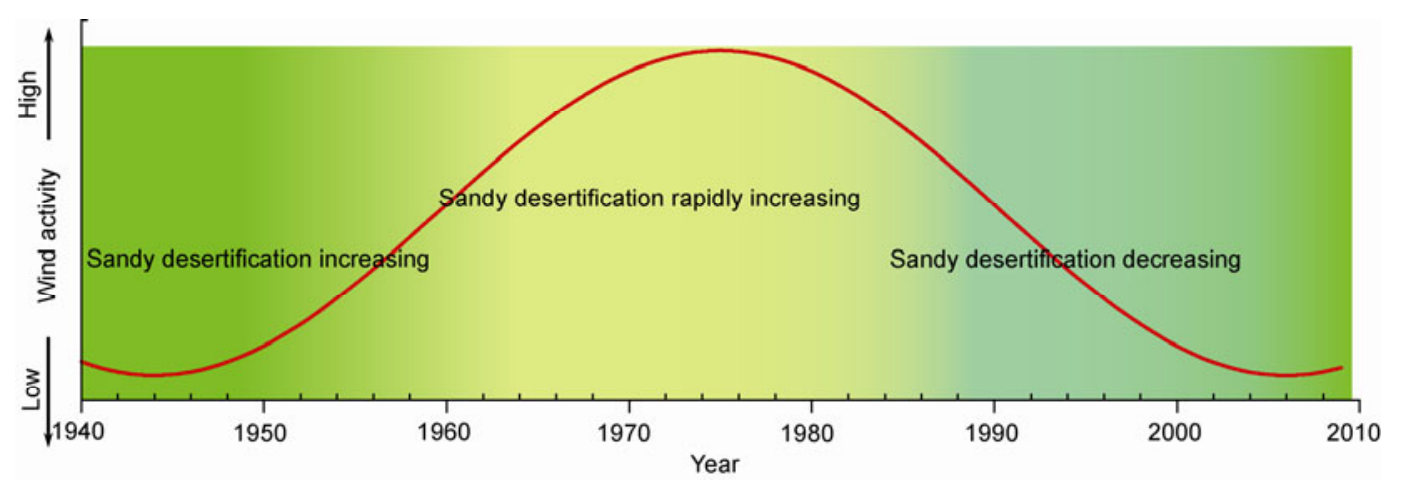

Figure 2 Relationship between variations in wind activity and desertification trends in arid, semiarid, and some semihumid areas of China (modified from Wang et al. [52]).

vegetation cover, erosion status, and accumulation status, can be classified into semi-mobile, semi-anchored, or anchored sandy land [31,33,62-64]. At global scales, sandy lands have developed in arid, semiarid, and semihumid areas with high vulnerability to sandy desertification. In addition, based on the current definition of sandy desertification, vegetation changes at the margins of deserts with mobile sands are also likely to increase the risk of sandy desertification. Depending on how dune activity changes, sandy desertification may increase or decrease.

Due to the influence of vegetation cover on wind activity and the influence of variations in wind intensity, the relationship between the vegetation cover and wind activity has been extensively studied $[65,66]$. There appears to be a threshold value for vegetation cover that determines whether sandy desertification will increase or decrease; at vegetation cover values higher than this threshold, the aeolian sediments transported by the wind will deposit on dune surfaces, dune activities will decrease, and desertification will reverse, whereas at lower vegetation cover, erosion will continue and desertification will expand. However, there are significant differences in the threshold values among dune fields. For instance, in the Kalahari Desert of South Africa, this value was $14 \%$ [67], versus $40 \%$ in the Mu Us Desert of China [68] and about $30 \%$ in the dune fields of Australia [69]. Although the main target of these studies was to reveal the dynamic processes that affect individual dunes, these studies of dune surfaces showed that when the degree of anchoring of the dunes by vegetation strengthened, sandy desertification decreased, whereas sandy desertification increased with decreasing anchoring. In addition, when fine particles accumulated on dune surfaces as a result of the presence of vegetation, the moisture and nutrient conditions improved [70], and a "fertilizer island" effect was observed [71] during the formation of vegetated dunes, decreasing the rate of sandy desertification.

In areas of sandy land and at the margins of deserts with mobile sands, vegetated dunes are the dominant landscape feature. Thus, the spatial and temporal trends in dune activity may reveal the desertification events that have occurred in these regions, and a dune activity index can be used as an indicator of the occurrence of sandy desertification [55,57]. The concept of a dune activity index was promoted by Cooke and Warren in the 1970s [72], and due to its ease of use [73], the index has been gradually improved and applied in many subsequent aeolian studies. One of the most widely used indices is the Lancaster dune mobility index [74], which is calculated as

$$
M=W /(P / P E),
$$

where $M$ is the mobility index (dimensionless), $W$ is the proportion of the year (\%) when wind velocity is greater than the threshold for sand transport, $P$ is the annual precipitation $(\mathrm{mm})$, and $P E$ is the annual potential evaporation (mm) estimated using Thornwaite's (1948) method. The higher the index value, the greater the dune activity.

The recent variations in dune activity of most major dune fields, including those in South Africa, in Arizona and New Mexico of the United States, in Australia, in Wales of the United Kingdom, and in arid, semiarid, and semihumid regions of China have been discussed in detail. For instance, in the Kalahari Desert of South Africa, a period with higher than average dune activity occurred in the 1980s and 1990s $[67,75,76]$. In the dune fields of Arizona and New Mexico, a period with higher than normal activity occurred in the late 1990s [73], whereas at the margins of China's Taklimakan Desert, this period was in the 1960s to the 1970s [57] and was from the mid-1970s to the mid-1980s in the Mu Us Sandy Land [47].

Although some scholars have attributed the observed sandy desertification to human activities, this opinion has been challenged by recent research advances for areas such as the Sahel region of Western Africa, which has sustained severe sandy desertification in recent decades [77,78]. In addition, because calculations of Lancaster's dune activity index depend strongly upon climate parameters, the variations in dune activity index strongly reflect natural factors such as climate change, and are strongly reflected in a region's sandy desertification trends. Therefore, by combining calculations of dune mobility with remote-sensing data on 
trends in sandy desertification during different periods within a given region, it has been possible to determine the relative strengths of the effects of human activities and climate change on sandy desertification.

Variations in dune activity in arid, semiarid, and semihumid China and their relationships with sandy desertification have been discussed in detail [52]. However, studies in other global dune fields have focused on South Africa and Australia. Some researchers have insisted that after sandy desertification occurs in a region, the soil productivity is permanently degraded, and that this process is irreversible on a human time scale [79]. However, most scholars now believe that climate changes such as increases in precipitation and in human activities such as measures to rehabilitate the soil and conserve water may allow vegetation to recover [80]. This agrees with the conclusions of Chinese scholars that sandy desertification can be reversed. Studies based on remote-sensing methods have shown periods of relatively high vegetation cover since ca. 1950: in the dune fields of Burkina Faso, which is located in the southwestern Sahara Desert, this period occurred in the late 1990s [81]; it occurred from the 1950s to the mid-1960s in northeastern Australia [82] and from the mid-1980s to the early 1990s in the southwestern United States [83]. In each of these regions, the periods with higher vegetation cover were associated with lower dune activity. These studies show that natural factors (and especially climate change) played a major role in the trend in sandy desertification, and that using a dune activity index can reliably indicate the balance between sandy desertification and vegetation recovery.

After extensive validation of the reliability of a dune activity index, including in studies of the effects of global warming on desertification, Thomas et al. [84] employed a modified version of the Lancaster index to predict dune activity trends in South Africa in the 21st century. Their analyses suggested that sandy desertification trends were controlled primarily by climate change in this region. Their simulations predicted significantly increased dune activity in the southern dune fields by 2039 and in the eastern and northern dune fields by 2069. By 2099, all dune fields will become highly dynamic in this region. The results suggest pessimism about efforts to control sandy desertification in South Africa during the 21 st century. Similarly negative predictions have been made for sandy desertification trends in the 21 st century in arid, semiarid, and some semihumid areas of China. Wang et al. [85] predicted that from 2010 to 2039 , most of these regions will not exhibit significant changes in their sandy desertification status, but that from 2040 to 2099, the environments of the western and eastern regions will deteriorate due to the significant effects of global warming, leading to decreased livestock and grain yields, possibly threatening China's food security.

After the studies of Thomas et al. [84] and Wang et al. [85], studies of sandy desertification, vegetation recovery, and dune activity at various spatial and temporal scales have been carried out around the world in different dune fields [64,86-93]. Because of severe wind erosion, other areas with high risks of sandy desertification include steppes and areas of reclaimed grasslands [94]. For instance, in the steppes of the Mongolian Plateau, the arid and cold climate is a major factor that controls sandy desertification [95], but no distinct aeolian geomorphologies have developed that provide signs of expanding sandy desertification. However, the wind activity in these regions is sufficiently intense that it not only erodes fine particles, causing a loss of the associated nutrients, but also increases evaporation [96] and decreases the availability of moisture to support plant growth. Thus, it has indirectly increased sandy desertification in the region. In areas of reclaimed grasslands, the variations in wind activity were also a key factor that controlled sandy desertification, because the vegetation cover during the windy season is very low [57], and provides little protection for the erodible fine particles against the wind; as a result, these particles are eroded and the surface soils are impoverished. At present, especially in arid and semiarid China, most studies have mainly focused on spatial variations in the intensity of wind erosion [97,98], and there have been few studies of its association with sandy desertification.

\section{Some unresolved issues related to sandy desertification}

From the perspective of the primary erosive force, sandy desertification has been defined as a predominantly aeolian process. There has been little research on sandy desertification of humid and sub-arctic regions, and most studies of sandy desertification have focused on the margins of deserts with mobile sands, sandy lands, steppes, grassland reclamation areas, and dryland farming areas [99-104]. Other regions with relatively low vegetation cover, such as mobile and gobi deserts, have generally been excluded from the category of sandy desertification. However, some of these regions, including gobi deserts, also undergo sandy desertification; except for a few regions such as the central Taklimakan and Badain Jaran deserts, where there is no vegetation cover on the dune surfaces, some vegetation cover remains on dune surfaces, although it is usually less than $15 \%$ [22]. The areas with fully mobile dunes account for only a small proportion of these deserts. Therefore, despite the low vegetation cover, the physiological characteristics of the xeromorphic vegetation result in relatively high belowground biomass [105].

In addition, the inter-dune areas that develop in deserts with mobile dunes are also major aeolian geomorphic units, and their areas typically equal those of the areas with mobile dunes, and the inter-dune surfaces also have some vegetation. Most of the gobi deserts that cover extensive areas of central Asia also have at least some vegetation. In regions of mobile deserts and in gobi deserts, some human 
activities affect the landscape and some wild animals exist (Figure 3). Therefore, under the impact of climate change or human activities, sandy desertification may occur in these regions. Unfortunately, the sandy desertification processes in these areas remain poorly understood. Definitive studies of the responses of vegetation activity to near-surface airflows, the evolution processes caused by wind activity, and their relationships with sandy desertification and vegetation rehabilitation do not yet exist for regions with high wind activity. Nonetheless, the definition of sandy desertification should be expanded to include gobis, mobile deserts and other areas that undergo this form of desertification.

In addition, studies of sandy desertification have not been integrated with other desertification issues or processes that occur simultaneously. For example, the salinization that occurs in arid, semiarid, and some semihumid areas is a serious environmental issue, and always accompanies sandy desertification [106]. In regions such as the edges of the Tarim Basin, the Hexi Corridor, and the Ala Shan Plateau, serious salinization occurs $[107,108]$ along with a high risk of sandy desertification. Salts are transported by running water produced by the rare rainfalls, by underground percolation, and by the wind [109]. After salts are transported to the ground surface by water, evaporation leads to concentration or even precipitation of salts, and the resulting salinization processes will be followed by sandy desertification processes. On the one hand, the salinization may be a key issue responsible for ecological deterioration; on the other hand, the significance of sandy desertification cannot be ignored. However, there have been few studies of the relationships between salinization and sandy desertification.

Water erosion is another neglected desertification issue. In most arid and semiarid zones, water does not seem to be an important factor at first glance because so little rainfall occurs. However, when rainfall does occur, it tends to be concentrated within a short period, increasing its erosive force. Water erosion usually interacts with wind erosion to complicate the process of sandy desertification. On the one hand, water flows create loose particles that are vulnerable to regional wind activity; on the other hand, these eroded materials can also be transported by water erosion. Water and wind erosion may occur alternately, or at different locations at a given time, and in some areas, erosive landscapes develop as a result of both wind and water erosion, and typical desertification geomorphologies develop [110]. However, until recently, there have been no rigorous studies of the relationship between wind erosion and water erosion. The extensive sedimentary records preserved in the alternation of geologic strata [111] contain signals of wind and water processes responsible for the genesis of the strata, and have provided insights into the wind-water erosion system [112]. As a result, such studies have become a hotspot for researchers. In China, researchers have investigated the concept of a "water-wind erosion system" since the mid1980s [113], and there have been some advances such as delineation of the size of the areas that have undergone

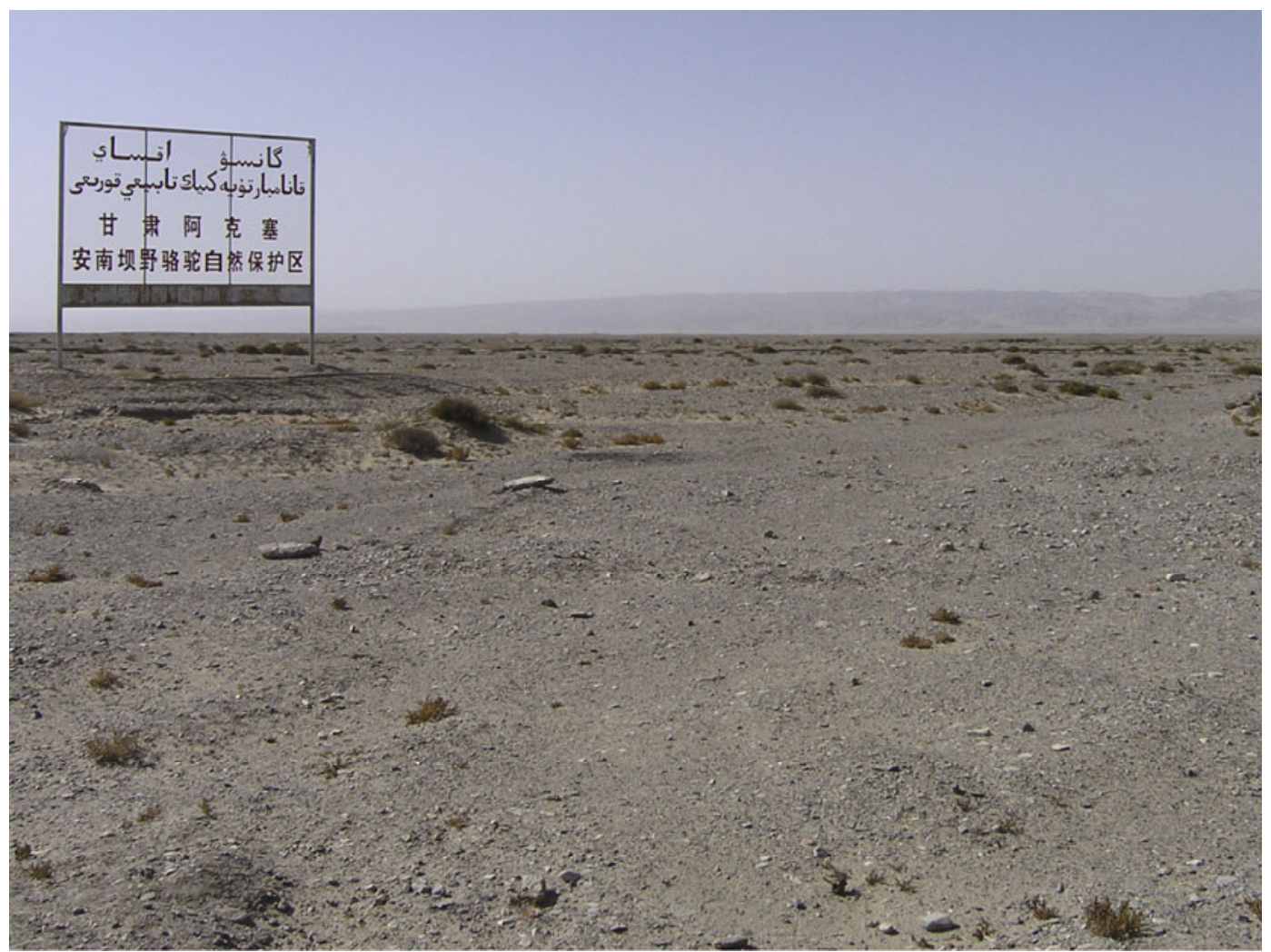

Figure 3 Gobi surfaces with a low vegetation cover are also regions where sandy desertification occurs. 
wind-water erosion, the spatial and temporal trends in these processes, and their characteristics [114]. However, the relative roles of wind and water erosion in modern sandy desertification and their respective mechanisms remain poorly understood.

The final central issue that needs to be resolved relates to the roles of biological processes and physical processes in sandy and aeolian desertification. As far as the biological processes are concerned, there have been many studies to expose the underlying mechanisms, but due to my limited knowledge I cannot provide more comments about this field of research. Although the physical processes involved in sandy desertification have been studied in far more detail, the consensus based on current research is surprisingly simplistic: we known that high wind activity increases sandy desertification, that desertification decreases during periods of low wind activity, and that vegetation plays some role in moderating the effects of wind. As the summary of the effects of vegetation cover in the previous section showed, both the biological and the physical processes involved in sandy desertification are important, and as in the case of wind-water erosion, their joint effects must be studied. In particular, the relationships among vegetation cover, biomass, and ecological succession to produce different species assemblies must be clarified for regions that are undergoing sandy desertification. Wind activity plays a role in sandy desertification by means of erosion, transportation, and accumulation of aeolian sediments, but these processes are superimposed on the processes that affect moisture conditions, nutrient conditions, plant growth, and ecological succession. There are likely to be important feedbacks between these biological and physical processes that strongly affect sandy desertification processes. Therefore, future research should involve a multidisciplinary approach in which colleagues from different fields of research work together to provide a more comprehensive and integrated understanding of sandy desertification [115]. This more holistic understanding of desertification processes will provide a stronger foundation for future efforts to combat desertification.

\section{Concluding remarks}

A large body of research during the past century has provided a large and growing body of knowledge that provides an increasingly firm basis for combating desertification. Currently, the success of this research, combined with an environment favorable for scientific research, high attention by the public, and large inputs of funding by governments and international organizations, have provided a good opportunity for studies of sandy desertification. However, previous research has generally focused on single factors in isolation (e.g. human activities, physical processes, and biological processes). Because all of these factors interact, with important feedback processes, future research must attempt to integrate these factors to provide a more holistic view of the ensemble of processes leading to sandy desertification and its reversal. In addition, the regions where sandy desertification occurs must be expanded from the current focus on sandy lands, the margins of the mobile deserts, steppes, and reclaimed grasslands to include other land types such as deserts with mobile sands and gobi deserts.

The factors that control sandy desertification include more than just combinations of dynamic processes and their interactions with different types of surface materials. At different temporal and spatial scales, there are complicated relationships among these factors. However, at present, scholars have only studied sandy desertification in their respective fields, and there have been few crossover studies among different research fields. The use of high-precision instruments and new technologies, combined with collaborative research between the geological and biological sciences, will make it possible to analyze the full range of factors that affect sandy desertification. Future studies of sandy desertification are therefore likely to involve large, interdisciplinary research projects. This collaboration among colleagues from multiple disciplines will lead to remarkable progress in our understanding of sandy desertification.

This work was supported by the National Science Fund for Distinguished Young Scholars of China (41225001). We thank Geoff Hart for his detailed edit of this manuscript. We thank Prof. Yan Ping, Prof. Hasi, Lang Lili, and Hua Ting for their help with manuscript preparation, and Profs. $\mathrm{Li}$ Jijun, Dong Guangrong, Yang Gensheng, and Chen Guangting for their advice and constructive comments.

1 Zeng N. Drought in the Sahel. Science, 2003, 302: 999-1000

2 Sharp R. Desertification: Another mirage? Nature, 1977, 269: 367368

3 Dyson-Hudson R. Desertification as a social problem. Science, 1983, 221: 1365-1366

4 Moore P D. One man's view of desertification. Nature, 1981, 290: 529-530

5 Cloudsley-Thompson J L. Problems of desertification. Nature, 1977, 270: 548

6 Otterman J. Baring high-albedo soils by overgrazing: A hypothesized desertification mechanism. Science, 1974, 186: 531-533

7 Haynes J C V. Great sand sea and Selima sand sheet, eastern Sahara: Geochronology of desertification. Science, 1982, 217: 629-633

8 Jackson R D, Idso S B, Otterman J. Surface albedo and desertification. Science, 1975, 189: 1012-1015

9 Kedar E Y. No desertification mechanism. Science, 1976, 194: 747748

10 Otterman J. No desertification mechanism. Science, 1976, 194: 748749

11 Lavauden L. Les forêts du Sahara. Revue des Eaux et Forêts, 1927, 65: 265-277, 329-341

12 Dong Y X. Desertification and sandy desertification (in Chinese). Chin Sci Technol Terms J, 2000, 2: 18-21

13 Stebbing E P. The encroaching Sahara: the threat to the West African colonies. Geogr J, 1935, 85: 506-519

14 Rodd F, Falconer J D, Stebbing E P. The Sahara. Geogr J, 1938, 91 : 354-359

15 Dregne H E. Land degradation in the drylands. Arid Land Res Manage, 2002, 16: 99-132 
16 UN Secretariat of the Conference on Desertification (UNCD). Desertification: An overview. In: United Nations, ed. Desertification: Its Causes and Consequences. New York: Pergamon Press, 1977. 121167

17 United Nations. Results of the World Conference on Environment and Development: Agenda 21. UNCED, United Nations Conference on Environment and Development, Rio de Janeiro. United Nations, New York, 1992

18 Wessels K J, Prince S D, Reshef I. Mapping land degradation by comparison of vegetation production to spatially derived estimates of potential production. J Arid Environ, 2008, 72: 1940-1949

19 Mabbutt J A, Floret C. Case Studies on Desertification. United Nation: UNESCO, 1980

20 Middleton N, Thomas D G S. World Atlas of Desertification: United Nations Environmental Programme. London: Edward Arnold, 1992

21 Zhu Z D, Chen G T. Sandy Desertification in China (in Chinese). Beijing: Science Press, 1994. 7-15

22 Zhu Z D, Wu Z, Liu S, et al. An General Introduction to Chinese Deserts (Revised Version, in Chinese). Beijing: Science Press, 1980

23 Zhu Z D. Current situation and prospect of land desertification problem (in Chinese). Geogr Res, 1994, 13: 105-113

24 Yang G S, Liu Y X, Shi P J. Several problems on desertification (in Chinese). Arid Zone Res, 1986, 3: 73-78

25 Dong G R, Shen J Y, Jin J, et al. Conceptions of desertification and desertization (in Chinese). Arid Land Geogr, 1988, 11: 58-61

26 Wu Z. Superficial review about the desertification in the North zone of China (in Chinese). Acta Geogr Sin, 1991, 46: 266-276

27 Wu Z. Aeolian Geomorphology and Sand Controlling Engineering (in Chinese). Beijing: Science Press, 2003

$28 \mathrm{Wu}$ Z. Chinese Deserts and Its Combating (in Chinese). Beijing: Science Press, 2009

29 Zhu Z D. Concept, cause and control of desertification in China (in Chinese). Quat Sci, 1998, 18: 145-155

30 Shen Y, Zhang K, Wang X. Desertification (in Chinese). Beijing: China Environmental Science Press, 2001

31 Wu Z. Aeolian Geomorphology (in Chinese). Beijing: Science Press, 1987

32 Pye K, Tsoar H. Aeolian Sand and Sand Dunes. Boston: Unwin Hyman, 1990

33 Livingstone I, Warren A. Aeolian Geomorphology: An introduction. Essex: Longman, 1996

34 Chepil W S, Woodruff N P. The physics of wind erosion and its control. Adv Agronomy, 1963, 15: 211-302

35 Buckley R. The effect of sparse vegetation on the transport of dune sand by wind. Nature, 1987, 325: 426-428

36 Lancaster N, Baas A. Influence of vegetation cover on sand transport by wind: field studies at Owens Lake, California. Earth Surf Proc Land, 1998, 23: 69-82

37 Nishimori H, Tanaka H. A simple model for the formation of vegetated dunes. Earth Surf Proc Land, 2001, 26: 1143-1150

38 El-Bana M I, Nijs I, Khedr A-H A. The importance of phytogenic mounds (nebkhas) for restoration of arid degraded rangelands in northern Sinai. Restor Ecol, 2003, 11: 317-324

39 Hugenholtz C H, Wolfe S A. Recent stabilization of active sand dunes on the Canadian prairies and relation to recent climate variations. Geomorphology, 2005, 68: 131-147

40 Kuriyama Y, Mochizuki N, Nakashima T. Influence of vegetation on aeolian sand transport rate from a backshore to a foredune at Hasaki, Japan. Sedimentology, 2005, 52: 1123-1132

41 Tsoar H. Sand dunes mobility and stability in relation to climate. Phys A, 2005, 357: 50-56

42 Durán O, Herrmann H J. Vegetation against dune mobility. Phys Rev Lett, 2006, 97: 188001

43 Okin G S, Gillette D A, Herrick J E. Multi-scale controls on and consequences of aeolian processes in landscape change in arid and semiarid environments. J Arid Environ, 2006, 65: 253-275

44 Leenders J K, van Boxel J H, Sterk G. The effect of single vegetation elements on wind speed and sediment transport in the Sahelian zone of Burkina Faso. Earth Surf Proc Land, 2007, 32: 1454-1474
45 Herrmann H J, Durán O, Parteli E J R, et al. Vegetation and induration as sand dunes stabilizators. J Coastal Res, 2010, 24: 1357-1368

46 Tengberg A. Nebkha dunes as indicators of wind erosion and land degradation in the Sahel zone of Burkina Faso. J Arid Environ, 1995, 30: $265-282$

47 Wang X, Chen F H, Dong Z, et al. Evolution of the southern Mu Us Desert in north China over the past 50 years: an analysis using proxies of human activity and climate parameters. Land Degrad Dev, 2005, 16: 351-366

48 Maestre F, Escudero A. Is the patch size distribution of vegetation a suitable indicator of desertification processes? Ecology, 2009, 90: 1729-1735

49 Saiko T A, Zonn I S. Irrigation expansion and dynamics of desertification in the Circum-Aral region of Central Asia. Appl Geogr, 2000, 20: 349-367

50 Brown G. Factors maintaining plant diversity in degraded areas of northern Kuwait. J Arid Environ, 2003, 54: 183-194

51 Wang $\mathrm{X}$, Dong Z, Yan $\mathrm{P}$, et al. Wind energy environments and dunefield activity in the Chinese deserts. Geomorphology, 2005, 65: 33-48

52 Wang X, Chen F, Hasi E, et al. Desertification in China: An assessment. Earth-Sci Rev, 2008, 88: 188-206

53 Shen J, Wang Y, Yang X, et al. Paleosandstorm characteristics and lake evolution history deduces from investigation on lacustrine sediments-The case of Hongjiannao Lake, Shanxi Province. Chin Sci Bull, 2005, 50: 2355-2361

54 Wang X, Hasi E, Zhou Z, et al. Significance of variations in the wind energy environment over the past 50 years with respect to dune activity and desertification in arid and semiarid northern China. Geomorphology, 2007, 86: 252-266

55 Wang X, Chen F, Dong Z. The relative role of climatic and human factors in desertification in semiarid China. Glob Environ Change, 2006, 16: 48-57

56 Wang X, Li J, Dong G, et al. Responses of desertification to variations in wind activity over the past five decades in arid and semiarid areas in China. Chin Sci Bull, 2008, 53: 426-433

57 Wang X, Dong Z, Liu L, et al. Sand sea activity and interactions with climatic parameters in the Taklimakan Sand Sea, China. J Arid Environ, 2004, 57: 85-98

58 Zhao H. Bioprocesses of Desertification and the Mechanisms of Degraded Vegetation Rehabilitation (in Chinese). Beijing: Science Press, 2007

59 Anthonsen K L, Clemmensen L B, Jensen J H. Evolution of a dune from crescentic to parabolic form in response to short-term climatic changes: Råbjerg Mile, Skagen Odde, Denmark. Geomorphology, 1996, 17: 63-77

60 Liu G J, Zhang X M, Li X R, et al. Adaptive growth of Tamarix taklamakanensis root systems in response to wind action. Chin Sci Bull (Suppl 2), 2008, 53: 164-168

61 Wang X, Wang T, Dong Z, et al. Nebkha development and its significance to wind erosion and land degradation in semiarid northern China. J Arid Environ, 2006, 65: 129-141

62 Wei W. Respondence and feedback of modern sand deserts to climate change. Chin Sci Bull, 2000, 52: 1137-1142

63 Cooke R, Warren A, Goudie A. Desert Geomorphology. London: UCL Press, 1993

64 Marín L, Forman S L, Valdez A, et al. Twentieth century dune migration at the Great Sand Dunes National Park and Preserve, Colorado, relation to drought variability. Geomorphology, 2005, 70: 163183

65 Musick H B, Gillette D A. Field evaluation of relationships between a vegetation structural parameter and sheltering against wind erosion. Land Degrad Rehab, 1990, 2: 87-94

66 Wolfe S A. Impact of increased aridity on sand dune activity in the Canadian Prairies. J Arid Environ, 1997, 36: 421-432

67 Wiggs G F S, Thomas D S G, Bullard J E, et al. Dune mobility and vegetation cover in the Southwest Kalahari desert. Earth Surf Proc Land, 1995, 20: 515-529

68 Huang F, Niu H, Wang M, et al. The relationship between vegetation 
cover and sand transport flux at Mu Us Sandland (in Chinese). Acta Geogr Sin, 2001, 56: 700-710

69 Ash J E, Wasson R J. Vegetation and sand mobility in the Australian desert dunefield. Z Geomorphol (Suppl), 1983, 45: 7-25

70 Shumway S W. Facilitative effects of a sand shrub on species growing beneath the shrub canopy. Oecologia, 2000, 124: 138-148

71 Garner W, Steinberger Y. A proposed mechanism for the formation of 'fertile islands' in the desert ecosystem. J Arid Environ, 1989, 16: 257-262

72 Cooke R U, Warren A. Geomorphology in Deserts. London: Batsford, 1973

73 Lancaster N, Helm P. A test of a climatic index of dune mobility using measurements from the southwestern United States. Earth Surf Proc Land, 2000, 25: 197-207

74 Lancaster N. Development of linear dunes in the southwestern Kalahari, Southern Africa. J Arid Environ, 1988, 14: 233-244

75 Bullard J E, Thomas D S G, Livingstone I, et al. Wind energy variations in the southwestern Kalahari Desert and implications for linear dunefield activity. Earth Surf Proc Land, 1996, 21: 263-278

76 Bullard J E, Thomas D S G, Livingstone I, et al. Dunefield activity and interactions with climatic variability in the Southwest Kalahari Desert. Earth Surf Proc Land, 1997, 22: 165-174

77 Mortimore M, Turner B. Does the Sahelian smallholder's management of woodland, farm trees, rangeland support the hypothesis of human-induced desertification? J Arid Environ, 2005, 63: 567-595

78 Herrmann S M. Human-environment relationships in drylands with A focus on the West African Sahel. Dissertation for Doctoral Degree. Arizona: The University of Arizona, 2006

79 Schlesinger W H, Reynolds J F, Cunningham G L, et al. Biological feedbacks in global desertification. Science, 1990, 247: 1043-1048

80 Hobbs R J, Harris J A. Restoration ecology: Repairing the Earth's ecosystems in the New Millennium. Restor Ecol, 2001, 9: 239-246

81 Rasmussen K, Fog B, Madsen J E. Desertification in reverse? Observations from northern Burkina Faso. Glob Environ Change, 2001, 11: 271-282

82 Fensham R J, Fairfax R J, Archer S R. Rainfall, land use and woody vegetation cover change in semiarid Australian savanna. J Ecol, 2005, 93: 596-606

83 Kepner W G, Watts C J, Edmonds C M, et al. A landscape approach for detecting and evaluating change in a semiarid environment. Environ Monit Assess, 2000, 64: 179-195

84 Thomas D S G, Knight M, Wiggs G F S. Remobilization of southern African desert dune systems by twenty-first century global warming. Nature, 2005, 435: 1218-1221

85 Wang X, Yang Y, Dong Z, et al. Responses of dune activity and desertification in China to global warming in the twenty-first century. Glob Planet Change, 2009, 67: 167-185

86 Fitzsimmons K E, Rhodes E J, Magee J W, et al. The timing of linear dune activity in the Strzelecki and Tirari Deserts, Australia. Quat Sci Rev, 2007, 26: 2598-2616

87 del Valle H F, Rostagno C M, Coronato F R, et al. Sand dune activity in northeastern Patagonia. J Arid Environ, 2008, 72: 411-422

88 Chase B M, Brewer S. Last Glacial Maximum dune activity in the Kalahari Desert of southern Africa: Observations and simulations. Quat Sci Rev, 2009, 28: 301-307

89 Forman S L, Nordt L, Gomez J, et al. Late Holocene dune migration on the south Texas sand sheet. Geomorphology, 2009, 108: 159-170

90 Hanson P R, Joeckel R M, Young A R, et al. Late Holocene dune activity in the Eastern Platte River Valley, Nebraska. Geomorphology, 2009, 103: 555-561

91 Girardi J D, Davis D M. Parabolic dune reactivation and migration at Napeague, NY, USA: Insights from aerial and GPR imagery. Geomorphology, 2010, 114: 530-541

92 Salvati L, Bajocco S. Land sensitivity to desertification across Italy: Past, present, and future. Appl Geogr, 2011, 31: 223-231
93 Qi Y, Chang Q, Jia K, et al. Temporal-spatial variability of desertification in an agro-pastoral transitional zone of northern Shanxi Province, China. Catena, 2012, 88: 37-45

94 Breshears D D, Whicker J J, Johansen M P, et al. Wind and water erosion and transport in semiarid shrubland, grassland and forest ecosystems: quantifying dominance of horizontal wind-driven transport. Earth Surf Proc Land, 2003, 28: 1189-1209

95 Begzsuren S, Ellis J E, Ojima D S, et al. Livestock responses to droughts and severe winter weather in the Gobi Three Beauty National Park, Mongolia. J Arid Environ, 2004, 59: 785-796

96 Monteith J L. Evaporation and environment. Water Plant, 1965, 205234

97 Li F R, Kang L F, Zhang H, et al. Changes in intensity of wind erosion at different stages of degradation development in grasslands of Inner Mongolia, China. J Arid Environ, 2005, 62: 567-585

98 Li J, Okin G S, Alvarez L, et al. Quantitative effects of vegetation cover on wind erosion and soil nutrient loss in a desert grassland of southern New Mexico, USA. Biogeochemistry, 2007, 85: 317-332

99 Barth H J. Desertification in the Eastern Province of Saudi Arabia. J Arid Environ, 1999, 43: 399-410

100 Wu B, Ci L. Landscape change and desertification development in the Mu Us Sandland, Northern China. J Arid Environ, 2002, 50: 429444

101 Amin A A. The extent of desertification on Saudi Arabia. Environ Geol, 2004, 46: 22-31

102 Asner G P, Heidebrecht K B. Desertification alters regional ecosystem-climate interactions. Glob Change Biol, 2005, 11: 182-194

103 Adamo S B, Crews-Meyer K A. Aridity and desertification: Exploring environmental hazards in Jáchal, Argentina. Appl Geogr, 2006, 26: 61-85

104 Guo J, Wang T, Xue X, et al. Monitoring aeolian desertification process in Hulunbir grassland during 1975-2006, Northern China. Environ Monit Assess, 2010, 166: 563-571

105 Li C P, Xiao C W. Above- and belowground biomass of Artemisia ordosica communities in three contrasting habitats of the Mu Us Desert, northern China. J Arid Environ, 2007, 70: 195-207

106 Thomas D S G, Middleton N J. Salinization: New perspectives on a major desertification issue. J Arid Environ, 1993, 24: 95-105

107 Wang Z Q, Zhu S Q, Yu R P, et al. Saline Soils of China (in Chinese). Beijing: Science Press, 1993. 273-305

108 Qian Y B, Wu Z N, Zhang L Y, et al. Spatial patterns of ephemeral plants in Gurbantünggüt Desert. Chin Sci Bull, 2007, 52: 3118-3127

109 Wang X, Hua T, Zhang C, et al. Aeolian salts in Gobi deserts of the western region of Inner Mongolia: Gone with the dust aerosols. Atmos Res, 2012, 118: 1-9

$110 \mathrm{Xu} \mathrm{J}$. Physico-geographical factors for the formation of hyperconcentrated flows in the Loess Plateau of China (in Chinese). Acta Geogr Sin, 1999, 54: 318-326

111 Langford R P, Chan M A. Fluvial-aeolian interactions: Part II, ancient systems. Sedimentology, 1989, 36: 1037-1051

112 Nanson G C, Tooth S, Knighton A D. A global perspective on dryland rivers: Perceptions, misconceptions and distinctions. In: Bull L J, Kirkby M J, eds. Dryland Rivers: Hydrology and Geomorphology of Semiarid Channels. West Sussex: John Wiley \& Sons Ltd, 2002. $17-54$

113 Team of Synthetic Research on Loess Plateau, Chinese Academy of Sciences. Synthetic Controls on Desertification in the North Loess Plateau (in Chinese). Beijing: Science Press, 1991

114 Zhang P. Spatial and temporal variability of erosion by water and wind in water-wind erosion crisscross region-Taking Liudaogou watershed in Jin-Shan-Meng contiguous areas as an example (in Chinese). J Soil Erosion Soil Water Conserv, 1999, 5: 93-96

115 Reynolds J F, Smith D M S, Lambin E F, et al. Global desertification: Building a science for dryland development. Science, 2007, 316: $847-851$

Open Access This article is distributed under the terms of the Creative Commons Attribution License which permits any use, distribution, and reproduction in any medium, provided the original author(s) and source are credited. 